REVIEW

MECHANISMS IN ENDOCRINOLOGY

\title{
Pathogenesis of type 2 diabetes in South Asians
}

\author{
Leontine E H Bakker ${ }^{1, *}$, Maria A Sleddering ${ }^{1, *}$, Jan W Schoones ${ }^{2}$, A Edo Meinders ${ }^{1}$ and Ingrid M Jazet $^{1}$ \\ ${ }^{1}$ Department of General Internal Medicine and Endocrinology and ${ }^{2}$ Walaeus Library, Leiden University Medical Center, PO Box 9600 , \\ 2300 RC Leiden, The Netherlands \\ (Correspondence should be addressed to L E H Bakker; Email: l.e.h.bakker@lumc.nl)
}

*(L E H Bakker and M A Sleddering contributed equally to this work.)

\begin{abstract}
The risk of developing type 2 diabetes mellitus (T2DM) is exceptionally high among both native and migrant South Asians. T2DM occurs more often and at a younger age and lower BMI, and the risk of coronary artery and cerebrovascular disease, and renal complications is higher for South Asians compared with people of White Caucasian descent. The high prevalence of T2DM and its related complications in South Asians, which comprise one-fifth of the total world's population, poses a major health and socioeconomic burden. The underlying cause of this excess risk, however, is still not completely understood. Therefore, gaining insight into the pathogenesis of T2DM in South Asians is of great importance. The predominant mechanism, in this ethnicity seems to be insulin resistance (IR) rather than an impaired $\beta$-cell function. In this systematic review, we describe several possible mechanisms that may underlie or contribute to the increased IR observed in South Asians.
\end{abstract}

European Journal of Endocrinology 169 R99-R114

\section{Introduction}

The worldwide prevalence of type 2 diabetes mellitus (T2DM) increases, particularly in South Asian countries, and especially in India, which currently has the highest global number of diabetes patients, with an estimated prevalence of up to $16.8 \%$ in urban areas $(1,2,3,4)$. Similar prevalence rates have also been reported in migrants of South Asian descent (India, Pakistan, Bangladesh, Nepal, and Sri Lanka) and in the USA, Canada, and various European countries (5, 6, 7, 8). In The Netherlands, South Asians mostly consist of Hindustani Surinamese who migrated from Surinam, a former Dutch colony in South America, and whose ancestors came from the Indian subcontinent about a century ago. Hindustani Surinamese have the highest T2DM prevalence of all ethnic minorities living in The Netherlands (9). An age-standardized prevalence rate of T2DM of $26.7 \%$ for this group has been reported, compared with 5.5\% in ethnic Dutch (10) (Table 1).

In addition to the increased prevalence, South Asians develop diabetes at a much younger age than White Caucasians and have an increased incidence of retinopathy, microalbuminuria, and end-stage renal disease $(11,12,13)$. Furthermore, South Asians have an increased risk of developing coronary artery and cerebrovascular disease, and a 50\% higher age-adjusted mortality rate from coronary heart disease (8).

Uncovering the underlying mechanisms involved in the higher prevalence of T2DM in South Asians is very relevant, as they represent over $20 \%$ of the world's population. In this review, we discuss the available literature on potential pathophysiological mechanisms responsible for the increased prevalence of T2DM in South Asians compared with White Caucasians.

\section{Methods}

The literature was searched using international databases: PubMed (1949 to July 2013), EMBASE (OVID-version, 1980 to July 2013), Web of Science (1945 to July 2013), and the Cochrane Library (1990 to July 2013). Terms used were 'South Asian' or 'Indo Asian', combined with several keywords related to diabetes and its risk factors (i.e. T2DM, obesity, metabolic syndrome, insulin resistance (IR), insulin secretion, body fat, liver fat, skeletal muscle, mitochondrial dysfunction, endothelial dysfunction, adipokines, and inflammation). References were limited to studies on humans, written in English or Dutch. See the Supplementary Methods in the section on supplementary data given at the end of this article for the complete literature search.

\section{T2DM in South Asians}

\section{Pathogenesis}

T2DM is a chronic, multifactorial disease characterized by a combination of IR and impaired insulin secretion 
Table 1 Prevalence of T2DM in South Asians and White Caucasians.

\begin{tabular}{lcc}
\hline & $\begin{array}{c}\text { Prevalence of } \\
\text { T2DM (\%) }\end{array}$ & References \\
\hline Rural India & $3.0-8.3$ & $(2)$ \\
Urban India & $10.9-14.2$ & $(2)$ \\
South Asians (Dutch) & 26.7 & $(10)$ \\
White Caucasians (Dutch) & 5.5 & $(10)$ \\
\hline
\end{tabular}

(14) (Fig. 1). The predominant mechanism, however, appears to be different in various ethnic groups.

Multiple studies have repeatedly shown that South Asians have higher fasting insulin concentrations compared with other ethnic groups regardless of age, gender, or BMI, suggesting a higher rate of IR in this population $(15,16,17,18,19,20,21,22,23,24,25)$. Already in South Asian neonates' the fasting insulin levels are markedly higher compared with European White Caucasian neonates' $(26,27)$, and fasting insulin remains higher in school children $(28,29)$ and teenagers (30). In addition, studies with an oral glucose tolerance test (OGTT) or meal tolerance test each show a higher serum insulin level after $2 \mathrm{~h}$ and/or a higher insulin area under the curve with a normal glucose response in South Asians compared with different ethnicities $(16,17,19,20,23,24,25,28,31,32)$. The response to an insulin tolerance test is also worse in South Asians $(31,32)$. Moreover, hyperinsulinemic euglycemic clamp studies performed in men and women of all age groups and relatively normal BMI show lower insulin sensitivity (up to almost 50\%) in South Asians compared with different ethnic populations $(16,18,21$, 23, 24, 25, 33, 34, 35, 36). Thus, South Asians seem to resemble Pima Indians, in whom also IR and hyperinsulinemia are predominant findings starting from a young age $(37,38)$.

Insulin secretion or $\beta$-cell function has been investigated in fewer studies and with more inferior techniques (e.g. no hyperglycemic clamp studies have been performed) compared with insulin sensitivity in South Asians. In a large study of the UK Prospective Diabetes Study (UKPDS) on 5098 newly diagnosed T2DM patients $(82 \%$ White Caucasians, $10 \%$ South Asians, and $8 \%$ Afro-Caribbeans), $\beta$-cell function, measured with homoeostasis model assessment (HOMA) $\beta$-cell function $(\% \mathrm{~B})$, was best in South Asians and worse in Afro-Caribbeans, while for insulin sensitivity, measured with HOMA \%S, the opposite was true (15). In another study, in which an intravenous glucose tolerance test was performed in 17 healthy first-degree relatives of patients with T2DM and 17 healthy controls with no family history of T2DM, insulin secretory defects prevailed in the European relatives $(n=10)$, whereas IR was predominant in the South Asian relatives $(n=7)$ (39). Similar results were found in a study in which an OGTT was performed in 260 middle-aged South Asians with different stages of glucose tolerance. They found that impaired glucose tolerance was not associated with a significant defect in insulin secretion, whereas IR was present already in an early stage of glucose intolerance, suggesting that IR might precede $\beta$-cell deficiency (40). Another study found that Asian Indian men $(n=21)$ had a $\sim 30 \%$ increase in basal $\beta$-cell responsivity, measured by the oral C-peptide minimal model, compared with White Caucasian men $(n=71)(22)$. Although this increase in $\beta$-cell function was inadequate for their degree of IR as reflected by a lower disposition index, this compensatory increase suggests that $\beta$-cell dysfunction is not the main problem. Hence, impairment in insulin secretion does not seem to be the primary defect in the development of T2DM in South Asians, in contrast to other ethnicities, such as Japanese and Afro-Caribbeans $(15,41,42)$.

In the next sections, we will describe several possible mechanisms that may contribute to the increased risk of T2DM, and in particular IR in South Asians.

\section{Evolutionary and developmental hypotheses}

The excess risk of T2DM among South Asians has been attributed to several hypotheses (Table 2).

The thrifty genotype hypothesis states that predisposition to diabetes must have evolved as an adaptive trait in certain environmental situations which later turned disadvantageous due to changes in life style. According to Neel (43), the thrifty genotype helped survival in the 'feast-or-famine days of hunting and gathering cultures', but has now turned detrimental in the modern era of 'continuous feasting'. In line with the thrifty genotype hypothesis, other evolutionary theories, such as the adipose tissue overflow (44) (see 'Body composition and fat distribution'), El Niño (45), and the variable disease selection (46) hypotheses, postulate that South Asians are particularly susceptible to central obesity and

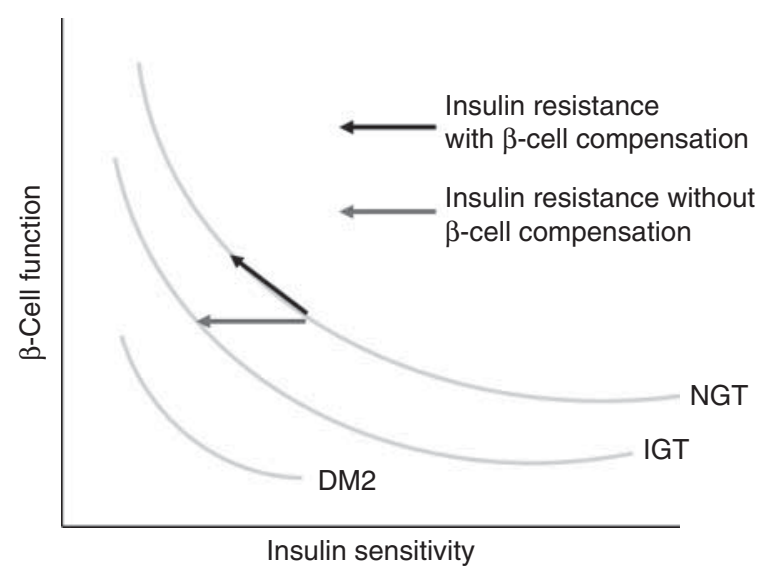

Figure 1 The relation between insulin sensitivity and $\beta$-cell function in type 2 diabetes. $\beta$-Cell function adapts to insulin resistance in order to maintain glucose tolerance normal (derived from thesis I M Jazet, ch 1, p 25, 2006). 
Table 2 Evolutionary and developmental hypotheses explaining the excess risk of T2DM among South Asians.

\begin{tabular}{|c|c|c|}
\hline Hypothesis & Description & Arguments pro/contra \\
\hline \multicolumn{3}{|c|}{ Evolutionary hypotheses } \\
\hline Thrifty genotype (43) & $\begin{array}{l}\text { Predisposition to T2DM must have evolved as an adaptive } \\
\text { trait in certain environmental situations that later turned } \\
\text { disadvantageous due to changes in lifestyle }\end{array}$ & $\begin{array}{l}\text { Does not explain why South Asians, in particular, } \\
\text { are susceptible to central rather than peripheral } \\
\text { obesity, or why central obesity is more import- } \\
\text { ant than generalized obesity in relation to T2DM }\end{array}$ \\
\hline $\begin{array}{l}\text { Adipose tissue } \\
\text { compartment (44) }\end{array}$ & $\begin{array}{l}\text { The primary adipose tissue compartment is less developed } \\
\text { in South Asians due to climatic influences, resulting in } \\
\text { early expansion of the secondary adipose tissue } \\
\text { compartment, especially in the face of excess energy } \\
\text { intake, eventually leading to metabolic disturbances such } \\
\text { as dysglycemia and dyslipidemia }\end{array}$ & $\begin{array}{l}\text { Explains why South Asians are particularly } \\
\text { susceptible to central obesity, and why White } \\
\text { Caucasians appear to be relatively protected } \\
\text { from metabolic abnormalities and diabetes }\end{array}$ \\
\hline El Niño (45) & $\begin{array}{l}\text { Susceptibility to central obesity and subsequently to IR } \\
\text { and T2DM is due to nutritional influences. Chronic } \\
\text { energy deficiency favors increased allocation to the } \\
\text { visceral depot }\end{array}$ & $\begin{array}{l}\text { Explains why South Asians are particularly } \\
\text { susceptible to central obesity } \\
\text { For many generations, South Asians have } \\
\text { endured fluctuations of energy supply, } \\
\text { associated in turn with global climate patterns } \\
\text { (El Niño) and geographic circumstances }\end{array}$ \\
\hline $\begin{array}{l}\text { Variable disease } \\
\text { selection (46) }\end{array}$ & $\begin{array}{l}\text { Susceptibility to central obesity and subsequently to IR } \\
\text { and T2DM is due to infectious influences. Exposures to } \\
\text { varying burdens of infectious disease may have been a } \\
\text { selective pressure accounting for genetic ethnic variability } \\
\text { in adipose tissue distribution }\end{array}$ & $\begin{array}{l}\text { Explains why South Asians are particularly } \\
\text { susceptible to central obesity } \\
\text { Chronic exposure to endemic gastrointestinal } \\
\text { diseases, including cholera, has been a } \\
\text { long-term stress in South Asian populations }\end{array}$ \\
\hline $\begin{array}{l}\text { Mitochondrial efficiency } \\
\text { hypothesis (47) }\end{array}$ & $\begin{array}{l}\text { Energy-producing efficiency of mitochondria enhanced the } \\
\text { successful adaptation of South Asians to climatic (heat) } \\
\text { and other nutritional exposures (periods of starvation). } \\
\text { Instead of using energy to generate heat, South Asian' } \\
\text { mitochondria are more likely to produce and subsequently } \\
\text { store energy. This mitochondrial efficiency might be } \\
\text { disadvantageous when adopting a new lifestyle with } \\
\text { low physical activity and a high caloric diet }\end{array}$ & $\begin{array}{l}\text { Explains the tendency of South Asians to obesity } \\
\text { per se, central obesity, and adverse metabolic } \\
\text { outcomes in our current environment, where } \\
\text { food is abundant and physical activity is low } \\
\text { Integrates other hypotheses, and offers a biologi- } \\
\text { cal mechanism (mitochondrial gene mutations) }\end{array}$ \\
\hline \multicolumn{3}{|c|}{ Developmental hypotheses } \\
\hline Thrifty phenotype (48) & $\begin{array}{l}\text { An intrauterine disadvantageous environment induces } \\
\text { thrifty mechanisms that set the metabolism to cope with } \\
\text { potential future food shortages, which is beneficial for } \\
\text { early survival, but increases the risk of T2DM later in life in } \\
\text { a nutrient rich environment. Based on strong association } \\
\text { between low birth weight and increased risk of T2DM later } \\
\text { in life, which is further increased by rapid weight gain } \\
\text { in childhood }\end{array}$ & $\begin{array}{l}\text { Low birth weight and rapid weight gain are } \\
\text { common in both native and migrant South } \\
\text { Asian neonates } \\
\text { Does not explain why South Asians are suscep- } \\
\text { tible to central rather than peripheral obesity, or } \\
\text { why central obesity is more important than } \\
\text { generalized obesity in relation to T2DM }\end{array}$ \\
\hline
\end{tabular}

subsequently to IR and T2DM due to selective evolutionary pressures (e.g. climatic, nutritional, or infectious). Recently, Bhopal \& Rafnsson have proposed the mitochondrial efficiency hypothesis: the energy-producing efficiency of mitochondria enhanced the successful adaptation of South Asians to climatic (heat) and other nutritional exposures (periods of starvation). Instead of using energy to generate heat, South Asian' mitochondria are therefore more likely to produce and subsequently store energy. This mitochondrial efficiency might be disadvantageous when adopting a new lifestyle with low physical activity and a high caloric diet, as is currently the case for South Asians (47). The study of Nair et al. (21) (discussed in 'Role of skeletal muscle') supports this hypothesis, in that they found higher mitochondrial capacity for oxidative phosphorylation (OXPHOS) in both nondiabetic and diabetic South Asians compared with nondiabetic White Caucasians.

Finally, according to the thrifty phenotype hypothesis, a developmental theory, there is a mismatch between intrauterine and adult life environments. An intrauterine disadvantageous environment (due to maternal malnutrition, maternal hyperglycemia, or other maternal/placental influences) induces thrifty mechanisms that sets the metabolism to cope with potential future food shortages, which is beneficial for early survival, but increases the risk of diabetes later in life in a nutrient rich environment $(48,49)$. This theory is based on the strong association between low birth weight and increased risk of T2DM later in life observed in a variety of ethnic populations (50). Low birth weight is common in both native and migrant South Asian neonates $(27,51,52)$. The risk to develop T2DM is further increased by rapid weight gain (catch-up growth) in childhood. This applies particularly to countries going through a rapid nutritional transition or when migration takes place from less developed to developed countries, as is the case for both native and migrant South Asians. Interestingly, recent studies in rats have shown that intrauterine growth 
restriction increases the susceptibility to high fat (HF)-diet-induced alterations of fat distribution, adipocyte size, lipid metabolism, and insulin-signaling pathways, supporting the thrifty phenotype hypothesis (53), and resembling the problem in South Asians.

Although these hypotheses help explain better why South Asians are at an increased risk of developing IR and T2DM, they do not give an exact molecular mechanism, except the mitochondrial efficiency hypothesis.

\section{Genetic factors}

T2DM is considered as a polygenic disease that involves polymorphisms of several genes with a high geneenvironment interaction (54). Many loci associated with T2DM have been found in White Caucasians; however, all variants found up till now have a modest effect size, with approximately twofold the lifetime prevalence rate of T2DM in persons carrying two copies of the risk allele compared with persons with no copies (55).

Most loci found in White Caucasians have been verified in studies with South Asian subjects (56, 57, 58), but few differences between the ethnic groups have been found and the differences are not all consistently shown. For example, Radha et al. (59) found that in South Asians the Pro12Ala polymorphism of the peroxisome proliferator activator $\gamma(P P A R \gamma)$ gene, which has a protective effect on T2DM development in white populations, is present at the same frequency in South Asians with and without diabetes and was not associated with a decreased risk of T2DM. However, in a study on Asian Indian Sikhs they did see a protective effect of the polymorphism, suggesting that there might be differences between specific South Asian groups (60). An interesting difference might lie in the fat-mass and obesity-associated (FTO) gene, which holds the strongest known obesity-susceptibility locus in Europeans. An association with T2DM has also been shown, but this seemed to be secondary to obesity. In South Asians, however, the FTO polymorphism was found to be associated with T2DM, independently of BMI $(61,62$, 63), implying that in South Asians there may be a different relationship between BMI and T2DM. However, associations between FTO and T2DM that were mediated by obesity have been found in South Asians as well (64) and in a study on North India none of the FTO variants was even associated with T2DM (65). Two other recent studies on South Asians found polymorphisms of genes being related to skeletal muscle: one associated with abdominal obesity and low lean body mass (myostatin) (66) and the other contributing to T2DM susceptibility (SCGC) (67), both of which merit further investigation.

Thus, so far no clear genetic differences between White Caucasians and South Asians have been found. Interestingly, most loci associated with T2DM are related to impaired $\beta$-cell function and insulin secretion, which are not considered the primary defects in the South Asian population, as discussed before. Therefore, differences between the two ethnic groups on these loci are unlikely. However, an exceptionally high percentage of South Asians have a positive family history of T2DM, making it likely that genetic differences are somehow involved in the increased prevalence of T2DM and IR in this ethnic group.

\section{Diet and exercise}

An unhealthy diet is a known risk factor for T2DM. Various studies have reported a number of dietary imbalances in South Asian diets associated with IR, such as high intake of total fat, saturated fatty acids, long chain $\omega-6$ polyunsaturated fatty acids (PUFA), trans fatty acids, and carbohydrates, and low intake of monounsaturated fatty acids, long chain $\omega-3$ PUFAs, fiber, and several micronutrients (e.g. magnesium, calcium, and vitamin D) $(68,69,70,71,72,73)$. Furthermore, children and adolescents already have a high intake of $\omega-6$ PUFA and a low intake of $\omega-3$ PUFA, which is correlated with fasting hyperinsulinemia (74, 75). However, supplementation of $\omega-3$ PUFAs (fish oil) did not improve insulin sensitivity in South Asians $(69,76)$. Moreover, other studies even reported that South Asian diets are healthier compared with White Caucasian diets (lower intake of fat) $(73,77$, 78, 79). Furthermore, different regional and religious South Asian communities in the UK had a similar, markedly higher prevalence of diabetes compared with white Europeans, despite the known dietary, cultural, and socioeconomic differences between these different South Asian communities. In addition, there were no discernible differences in the dietary customs of those with normal glucose tolerance, impaired glucose tolerance, and newly diagnosed T2DM $(80,81)$. Lack of exercise is another risk factor for T2DM. The 2004 Health Survey for England data reported lower levels of physical activity in South Asian groups compared with the general UK population and other ethnic minority groups (77), and other studies showed similar results in migrant and urban South Asians $(6,15,82,83$, $84,85,86,87)$. This low level of physical activity is already present in children and adolescents $(77,85,88$, $89,90,91)$.

Hence, although lifestyle factors will certainly play a role in the etiology of IR as they do in White Caucasians, there is no reason to assume that this role is any different between both ethnicities. This is strengthened by the fact that the excessive risk for T2DM applies to both native and migrant South Asians despite differences in lifestyle. Hence, South Asians seem to have an exceptionally high susceptibility to develop T2DM in the context of the same environmental pressure when compared with other ethnicities. 


\section{Body composition and fat distribution}

South Asians develop IR and T2DM at lower ranges of BMI than White Caucasians. An equivalent incidence rate of T2DM is seen at a BMI of $24 \mathrm{~kg} / \mathrm{m}^{2}$ in South Asians compared with $30 \mathrm{~kg} / \mathrm{m}^{2}$ in White Caucasian subjects (92). Gray et al. (93) even showed an equivalent level of dysglycemia at a BMI cutoff point of $22.6 \mathrm{~kg} / \mathrm{m}^{2}$ in South Asian males as compared with $30.0 \mathrm{~kg} / \mathrm{m}^{2}$ in White Caucasian males. In addition, a cross-sectional study of 4600 9- to 10-year-old children of South Asian, black African-Caribbean, and white European origin showed that South Asian children were more metabolically sensitive to adiposity as indicated by stronger positive associations between HOMA-IR and adiposity measures (94). It has been proposed that an increase in total fat mass and an adverse pattern of fat distribution contributes to the higher risk of T2DM in South Asians at similar BMI levels. Therefore, it has been suggested that ethnic-specific BMI cutoff values should be used for assessing diabetes risk in different populations.

Several studies have shown that South Asians have a higher percentage of body fat for comparable levels of BMI compared with White Caucasians and are therefore referred to as 'metabolically obese' $(16,23$, $34,95,96,97$ ) (Table 3). This is already apparent in children and adolescents $(98,99,100)$. Also, the distribution of fat differs between ethnicities. South Asian neonates exhibit the 'thin-fat phenotype', described as low muscle mass with preserved subscapular (central) fat $(27,101,102)$ and this phenotype is retained in Surinam South Asian babies of the fourth to fifth generation after migration from India (103). Modi et al. (104) showed that South Asian neonates have significantly increased abdominal adiposity compared with European babies and this increase in abdominal adiposity has also been observed in adults in several other studies $(16,23,34,95,96)$. The 'thinfat phenotype' is also apparent in prepubertal Indian children who have greater adiposity than White UK children despite significantly lower BMIs (29).

It is currently unclear as to which of the abdominal adipose tissue compartments, visceral adipose tissue (VAT) or subcutaneous adipose tissue (SAT), has the most detrimental effect on insulin sensitivity (44).

Table 3 Differences in body composition in South Asians vs White Caucasians.

\begin{tabular}{ll}
\hline South Asians vs White Caucasians & References \\
\hline Higher percentage of body fat & $(16,23,34,95,96,97)$ \\
Thin-fat phenotype in neonates & $(27,101,102,103)$ \\
Increased abdominal adiposity & $(16,23,34,95,96)$ \\
Increased VAT & $(23,96)$ \\
$\begin{array}{l}\text { Increased deep SAT; lower, or similar } \\
\text { superficial SAT }\end{array}$ & $(109,110)$ \\
$\begin{array}{l}\text { Decreased skeletal muscle mass/lean } \\
\text { body mass }\end{array}$ & $(16,95,109,146)$ \\
\hline
\end{tabular}

VAT, visceral adipose tissue; SAT, subcutaneous adipose tissue.
Banerji et al. (16) showed that South Asians have high amounts of VAT and that IR is correlated with total visceral and not with subcutaneous abdominal adipose tissue volume. Other studies also showed an association of VAT with diabetes (105) and cardiovascular risk factors in South Asians $(106,107)$. However, in a study by Raji et al. (23), insulin sensitivity measured with a hyperinsulinemic euglycemic clamp in healthy South Asians and White Caucasians was inversely related with VAT as well as abdominal SAT and total abdominal adipose tissue. This was, however, a small study including only 12 South Asian and 12 White Caucasian subjects. In another study on 171 South Asians, abdominal SAT was a better predictor of the metabolic syndrome. Also, SAT (and not VAT) was significantly correlated with IR; however, IR was measured by HOMA and data were available only for 46 patients (108). Furthermore, Chandalia et al. (34) showed that IR was present in South Asians who had higher percentages of total body fat and abdominal SAT, but similar amounts of VAT as compared with White Caucasians. However, these studies do not discriminate between superficial SAT (SSAT) and deep SAT (DSAT). It is believed that an increase in DSAT, similar to VAT, is associated with metabolic disturbances (44). Sniderman et al. (44) theorized in their 'overflow hypothesis' that SSAT is the primary adipose tissue compartment and DSAT and VAT are secondary compartments, which have adverse metabolic consequences. They propose that South Asians have a less developed primary compartment, resulting in earlier expansion of the secondary compartment, thereby leading to the increased risk of T2DM and CVD. Studies showing that South Asians have higher levels of DSAT and lower or similar amounts of abdominal SSAT as compared with White Caucasians support this hypothesis $(109,110)$.

Thus, South Asians have higher total fat mass than White Caucasians. This fat is primarily stored in the visceral and deep subcutaneous compartments and correlates with IR. This might be due to different metabolic characteristics of the adipocytes in this compartment as discussed below.

\section{Adipose tissue dysfunction and inflammation}

Not only the amount and distribution of body fat differs between South Asians and White Caucasians. It has been proposed that South Asians have abnormalities in adipocyte function as well (Table 4). Adipocytes serve as a buffer for the daily influx of fat. When adipocytes are overloaded, for example in the case of obesity, they become dysfunctional; the ability to store lipids is decreased (111). Studies have shown that South Asians have significantly increased subcutaneous adipocyte size $(34,109)$. Hypertrophic adipocytes are considered as dysfunctional and appear to be associated with IR in nondiabetic individuals independent of BMI and to be an independent predictor for the development of T2DM 
Table 4 Differences in adipose tissue in South Asians vs White Caucasians.

\section{South Asians vs White Caucasians References}

\begin{tabular}{ll}
\hline Increased adipocyte size & $(34,109,114)$ \\
Increased FFA release & $(115)$ \\
Increased leptin & $(18,22,115,117,118,119)$ \\
Decreased adiponectin & $(36,119,124,125)$ \\
Increased IL6 and TNF $\alpha$ release & $(22,131)$ \\
Increased CRP production & $(132,133)$
\end{tabular}

CRP, C-reactive protein.

(112, 113). Furthermore, Balakrishnan et al. (114) showed that South Asians not only have a higher fraction of very large adipocytes, but also exhibit a higher ratio of small-to-larger adipocytes, which is considered a defect in adipose tissue maturation, resulting in a decreased storage capacity of triglycerides (TG). Also, in a recent study, normoglycemic young South Asian men have shown increased expression of COL6A3 in SAT, which is known to reduce adipocyte maturation (36).

Adipocyte dysfunction was also shown in a study by Abate et al. (115), demonstrating that nondiabetic South Asians have higher fasting levels of free fatty acids (FFAs) compared with White Caucasians, even when adjusted for body fat content, and fail to completely suppress plasma FFA concentration during hyperinsulinemia induced by an OGTT. This suggests that in healthy South Asians, insulin is unable to sufficiently inhibit lipolysis, resulting in an excess efflux of FFA, which may play a role in the development of T2DM.

White adipose tissue not only has a function in the storage and release of FFAs, but is more and more recognized as an endocrine organ secreting several proteins called adipocytokines. Of those, leptin and adiponectin are the most frequently studied in relation to IR and T2DM. Leptin has an important role in food intake, energy expenditure, and glucose metabolism. Leptin seems to have a glucose- and insulin-lowering and insulin-sensitizing effect on the whole body level. Plasma leptin levels are positively correlated with plasma insulin, BMI, and body fat content, therefore obesity reflects a state of leptin-resistance (116). Plasma leptin levels were increased in South Asians as compared with White Caucasian subjects in several studies $(18,22,115,117$, 118,119 ) independent of overall or abdominal obesity. Leptin levels were found to be correlated with SAT and not with VAT $(16,120)$. However, in some of these studies a difference in fat mass was found between the two groups, or data on fat mass were not reported. Furthermore, in a recent study, no correlation has been shown between leptin and IR in South Asians (121).

In contrast to leptin, adiponectin is decreased in obesity, IR, and T2DM (122). Adiponectin is thought to exert insulin-sensitizing, antiatherogenic, and antiinflammatory effects (123). South Asians exhibit lower levels of adiponectin compared with White Caucasians
$(36,119,124)$. This is already evident in babies of 3-6 months old (125). Furthermore, lower adiponectin levels have been found in South Asians with impaired glucose tolerance and T2DM as compared with normal glucose-tolerant South Asian individuals $(121,126)$. In addition, low adiponectin levels were found to be an independent predictor for T2DM development in South Asians (127). However, another study showed no relation between adiponectin and insulin sensitivity in the South Asian group (128).

Dysfunctional adipose tissue also produces proinflammatory cytokines, such as tumour necrosis factor $\alpha$ (TNF $\alpha$ ) and interleukin 6 (IL6), leading to a chronic inflammatory state. Although not yet fully elucidated, it is hypothesized that activation of proinflammatory pathways, for example, in muscle, liver, and adipose tissue, leads to IR by inhibiting the insulin signaling cascade $(129,130)$. Middle-aged South Asian women exhibited significantly higher IL6 levels than Europeans; however, no ethnic difference in IL6 was detected among men (131). In young South Asian men, however, IL6 levels were found to be elevated compared with White Caucasians (22). In this study, TNF $\propto$ was elevated as well, yet this difference disappeared when correcting for insulin sensitivity. In addition, in comparison with White Caucasians, studies showed higher C-reactive protein (CRP) levels in South Asians, also suggesting a state of low-grade inflammation $(132,133)$. The primary production site of CRP is the liver, and not the adipose tissue. However, visceral fat is drained by the portal vein to the liver and CRP production is induced by cytokines, such as IL6 (129). In South Asians, visceral fat was positively associated with CRP levels, independent of total adiposity, and was associated with fasting and 2-h insulin levels during an OGTT (133).

In conclusion, dysfunctional adipose tissue and inflammation are likely to contribute to the South Asian phenotype of increased IR and T2DM. It is, however, difficult to determine the primary defect: adipocyte dysfunction leads to abnormalities in the insulin-signaling pathway, or vice versa: abnormal insulin signaling results in adipocyte dysfunction. Abate et al. (115) proposed that it might be a vicious cycle starting with primary IR, leading to adipose tissue dysfunction, which is reflected by the increased secretion of FFAs and (adipo)cytokines. The high levels of circulating FFAs in turn can aggravate the IR through the deposition of TG in the non-adipose tissues (134), also called ectopic fat.

\section{Ectopic fat}

IR and T2DM are associated with accumulation of ectopic fat, i.e. the storage of TG in non-adipose tissues such as the liver, heart, and skeletal muscle. Intracellular lipid deposition in these tissues is a consequence of oversupply of FFAs due to increased caloric intake, obesity, adipocyte dysfunction, increase in fatty acid 
transporters, and/or impairment in mitochondrial lipid oxidation. The subsequent accumulation of intermediates of lipid metabolism, such as long-chain acyl-CoA, diacylglycerol, and ceramids, in these organs appears to disrupt normal metabolic processes, causing organspecific dysfunction (134).

Deposition of fat in the liver in the absence of excessive alcohol intake is referred to as nonalcoholic fatty liver disease, and is associated with hepatic IR $(135,136)$. This is due to a reduction in insulin-stimulated hepatic glucose uptake and decreased insulin suppressibility of hepatic glucose production, which both contribute to increased plasma glucose levels (134). In South Asians, limited data have reported higher hepatic TG content in comparison with White Caucasians, as measured by ${ }^{1} \mathrm{H}$ MRS (22, 109). Petersen et al. (22) showed that young healthy South Asian men $(n=23)$ had a higher prevalence of IR, as assessed with an OGTT in combination with the insulin sensitivity index, which was associated with an approximately twofold increase in hepatic TG content compared with White Caucasian men $(n=73)$. Another study reported higher fat infiltration in the liver in adult South Asians $(n=56)$ vs White Caucasians $(n=52)$ (109). These data suggest that South Asians appear to be predisposed to develop hepatic steatosis, associated with hepatic IR.

In nonathletic White Caucasians, intramyocellular lipid (IMCL) accumulation is associated with IR and T2DM, due to its toxic effects on insulin signaling (137, $138,139)$. In South Asians, IMCL content seems to be higher compared with White Caucasians (22, 140). However, in contrast to White Caucasians, no correlation between IMCL and IR has been found in South Asians so far $(22,109,140,141,142,143)$. This suggests that IMCL is of less significance to skeletal muscle insulin sensitivity in South Asians compared with White Caucasians.

\section{Role of skeletal muscle}

Muscle glucose uptake accounts for $75-80 \%$ of wholebody insulin-stimulated glucose disposal (144). Total body muscle mass (relative to body size) has been shown to exert an independent effect on insulin sensitivity and glucose disposal (145). Several studies reported that skeletal muscle mass, or lean body mass, is lower in South Asians than in White Caucasians (16, 95, 97, $100,109,146)$. Furthermore, low muscle mass was associated with reduced insulin sensitivity in young, lean South Asian men (147). In studies conducted at our research center, we also found lower lean body mass in healthy young South Asian men compared with BMI-matched White Caucasians, as measured by dualenergy x-ray absorptiometry (DEXA)-scan (LEH Bakker, MR Boon, RAD Van der Linden, L Pereira Arias-Bouda, F Smit, JW Jukema, JT Tamsma, HJ Verberne, LM Havekes, WD Van Marken Lichtenbelt, IM Jazet and PCN Rensen 2013, unpublished data).
In White Caucasian T2DM patients, the primary defect at the skeletal muscle level seems to reside in nonoxidative glucose disposal, i.e. glycogen synthesis, due to impairments in insulin-stimulated GLUT4 translocation leading to impaired glucose transport (148, 149, 150). These impairments in the insulinsignaling pathway seem to be induced by defects in the oxidation of mitochondrial fatty acid and/or increased delivery of fatty acids, leading to IMCL accumulation. IMCL, in turn, can impair insulin signal transduction (134). Indeed, in T2DM patients several defects in the insulin-signaling pathway have been found (151). Furthermore, reduced mitochondrial density with reduced OXPHOS have been described in insulinresistant offspring of patients with T2DM (152). Moreover, maximal oxygen uptake, or $\mathrm{VO}_{2 \max }$ (a measure of whole-body oxidative capacity), is found to be a strong independent predictor of peripheral insulin sensitivity in White Caucasians $(153,154,155)$, and low cardiorespiratory fitness is associated with low skeletal muscle lipid oxidative capacity (156). One might speculate, therefore, that the increased risk of IR and T2DM in South Asians might be, at least in part, explained by reduced skeletal muscle oxidative capacity.

In South Asians, several studies reported lower $\mathrm{VO}_{2 \max }$ values in South Asians compared with White Caucasians $(89,146,157)$. A recent study by Ghouri et al. (97) has confirmed this finding in middle-aged South Asian men without T2DM $(n=87)$ compared with age- and BMI-matched European men $(n=99)$ and, importantly, found that the lower cardiorespiratory fitness showed $68 \%$ of the ethnic difference in HOMAIR. Of note, the lower $\mathrm{VO}_{2 \max }$ could not be explained by their lower levels of physical activity, indicating that low physical fitness is an innate feature of the South Asian phenotype. However, so far only two relatively small in-depth studies have been performed in South Asians, in which skeletal muscle biopsies were obtained to find out more about the molecular mechanisms of the increased risk of IR and T2DM in this ethnicity. In a study by Nair et al. (21) no impairment in mitochondrial function (measured as skeletal muscle mitochondrial capacity for OXPHOS as assessed by mitochondrial DNA (mtDNA) copy number, OXPHOS gene transcripts, citrate synthase activity, and maximal mitochondrial ATP production rate) was found in 13 healthy, middleaged South Asians living in the USA, despite the finding that they were more insulin resistant than 13 age-, sex-, and BMI-matched Northern European Americans. On the contrary, South Asians had even higher mitochondrial capacity for OXPHOS. Hall et al. (146) also reported that healthy, young, lean male South Asians $(n=20)$ compared with age- and BMI-matched White Caucasians $(n=20)$ did not exhibit lower expression of skeletal muscle oxidative and lipid metabolism genes, and mtDNA:nuclear DNA ratio (index of mitochondrial biogenesis) did not differ between groups. Gene expression of carnitine palmitoyltransferase $1 \mathrm{~A}(\mathrm{CPT} 1 \mathrm{~A})$ and 
fatty acid synthase (FASN), both involved in lipid metabolism, was even higher in South Asians. Consequently, both studies concluded that mitochondrial dysfunction did not account for the observed IR in South Asians. Importantly, Hall et al. (146) also showed that South Asians oxidized less fat during submaximal exercise, whereas the resting rate of fat oxidation did not differ between groups. This difference, however, was not reflected in reduced skeletal muscle expression of oxidative and lipid metabolism genes. It should be noted, however, that these results are derived from only two relatively small studies carried out in different age groups, and thus extrapolation of these results to the whole South Asian population should be done with caution.

The above-mentioned study of Hall et al. (146) is the only study that compared skeletal muscle insulin signaling between both ethnicities. Interestingly, this study showed that South Asians had reduced skeletal muscle protein expression of key insulin signaling proteins (phosphatidylinositol 3'-kinase p85 subunit (PI3K (p85)) and protein kinase B serine 473 phosphorylation (pPKB-Ser473)). Basal Ser473 phosphorylation of PKB was even $60 \%$ lower in South Asians, and was significantly correlated with wholebody insulin sensitivity. However, the expression of the insulin signaling proteins in the hyperinsulinemic condition was assessed in response to maximal insulin stimulation by incubating for $10 \mathrm{~min}$ in the presence of $10 \mathrm{nM}$ soluble human insulin, instead of using a hyperinsulinemic clamp. Hence, the meaning of this finding needs to be corroborated.

To summarize, South Asians have less skeletal muscle mass and seem to have lower cardiorespiratory fitness and reduced capacity for fat oxidation during submaximal exercise, all correlating with their reduced whole-body insulin sensitivity, which is not reflected in reduced expression of oxidative and lipid metabolism genes in the skeletal muscle (146). However, so far only two relatively small in-depth studies have been performed in South Asians; therefore, these results should be interpreted with caution and more research is warranted.

\section{Nitric oxide bioavailability: endothelial and HDL-cholesterol dysfunction}

Apart from the aforementioned metabolic functions, insulin also stimulates the release of nitric oxide (NO) from endothelium, which leads to peripheral vasodilatation, increased capillary recruitment, and increased blood flow. Subsequently, these hemodynamic actions increase the delivery of insulin to (underperfused) tissues and enhance the delivery of glucose and other substrates to the skeletal muscle. It is thought that $25-40 \%$ of insulin-mediated glucose disposal is due to its hemodynamic effects $(158,159)$.
Several studies have demonstrated that South Asians have lower NO bioavailability compared with White Caucasians $(160,161)$. NO is mainly produced by the endothelium as a consequence of an interaction with HDL-cholesterol (HDL-C) $(162,163)$. Thus, a diminished NO bioavailability might be caused by the dysfunction of the endothelium and/or dysfunctional HDL-C. To what extent lower NO availability is present in South Asians as well as its cause, endothelial or HDL-C dysfunction, or a combination of both, are yet unknown.

Endothelial dysfunction is defined as inadequate endothelial-mediated vasodilatation and is present in patients with obesity, dyslipidemia, diabetes, and very early in individuals with (a high risk of) atherosclerosis. IR and endothelial dysfunction are closely related. It has been shown that gluco- and lipotoxicity decrease NO availability (158, 159). In South Asians, impairments in endothelial function have been reported. Chambers et al. showed that endothelium-dependent dilatation (measured as brachial artery flow-mediated dilatation) was reduced in South Asians living in the UK compared with White Caucasians and this was confirmed by other studies $(161,164)$. In yet another study, although no difference in vasodilatation was observed after reactive hyperemia or sublingual nitroglycerin administration between the two ethnic groups, the increase in vasodilatation during hyperinsulinemia compared with basal conditions was significantly lower in South Asians (24). Signs of endothelial dysfunctions are already present early in life in South Asians. Din et al. (165) showed that healthy, young South Asian men have increased arterial stiffness (reflected by an increased augmentation of radial artery pressure waveforms) compared with healthy, young White Caucasians. Interestingly, in the cord blood of South Asian neonates an elevated level of E-selectin, a marker of endothelial dysfunction which has been shown to predict the occurrence of T2DM in adult women, was found, suggesting that endothelial dysfunction might already be present at birth (26). Furthermore, it was shown that South Asians have lower circulating numbers of endothelial progenitor cells (EPCs) and EPC colony forming units, which may result in a reduced capacity for endothelial repair $(160,161)$. However, others did not find a difference in the EPC count between South Asian and White Caucasian men with established atherosclerosis (166).

Besides endothelial dysfunction, HDL-C dysfunction might also play a role in the decreased NO bioavailability observed in South Asians. Multiple studies have consistently shown lower HDL-C levels in South Asians compared with White Caucasians (19, 20, 23, 33, 99, $132,167)$. Not only do they have lower levels of HDL-C, they also seem to have more small-dense dysfunctional HDL-C particles, which are thought to be proinflammatory and less protective compared with normal HDL-C (168). 
A diminished NO bioavailability in South Asians might thus be caused by both endothelial and HDL-C dysfunction, and might be a factor in the increased incidence of T2DM and cardiovascular diseases in this ethnic group.

\section{Conclusion and future directions}

The risk of developing T2DM is exceptionally high among both native and migrant South Asians, comprising one-fifth of the worlds' population. The disease develops about a decade earlier than in White Caucasians, and South Asians also have an increased incidence of retinopathy, nephropathy, and coronary artery and cerebrovascular disease. Even nondiabetic individuals have higher insulin levels compared with other ethnic groups regardless of age, gender, or BMI. This points to impaired insulin sensitivity (IS). Indeed, several studies have shown that the predominant mechanism leading to the increased risk of T2DM in South Asians seems to be IR rather than decreased $\beta$-cell function.

We have tried to review several pathogenetic factors that might underlie the increased and accelerated risk to develop IR and T2DM in South Asians, which is shown in Fig. 2.

Given the strong familial clustering of T2DM in South Asians, one would assume distinctive genetic differences between White Caucasians and South Asians. However, the presence of polymorphisms associated with T2DM found thus far does not clearly differ between the two ethnicities. It might be that either the wrong loci have been investigated (i.e. South Asians have different polymorphisms), the sample sizes were too small, or that the increased risk is caused by epigenetic differences. We believe that genetics or epigenetics must play a role, despite the fact that this has not been confirmed yet.

South Asians unmistakably have a different body composition than White Caucasians, with relatively thin extremities and increased abdominal adiposity, both in the visceral as well as in the deep subcutaneous compartments. Increased visceral and deep subcutaneous fat mass are associated with IR. Up till now, however, studies on South Asians show contradictory results with either an association of VAT with IR or of SAT with IR. Furthermore, South Asians appear to have dysfunctional adipocytes, leading to a decreased storage capacity for TG and impaired release of FFAs, adipokines, and proinflammatory cytokines, which are thought to disrupt the insulin-signaling pathway.

Remarkably, as of yet no convincing differences in intracellular signaling cascades and enzymatic process involved in insulin signaling have been found between South Asians and White Caucasians. However, so far only two relatively small studies obtained muscle biopsies and investigated mitochondrial function, and only one investigated the insulin signaling pathway. Some studies show differences in endothelial function, suggesting that perhaps impaired insulin-mediated capillary recruitment plays a role in the development of IR in South Asians. This would lead to diminished insulin delivery to its site of action. Hence, perhaps the fact that no difference in insulin signaling was observed is a quantitative problem.

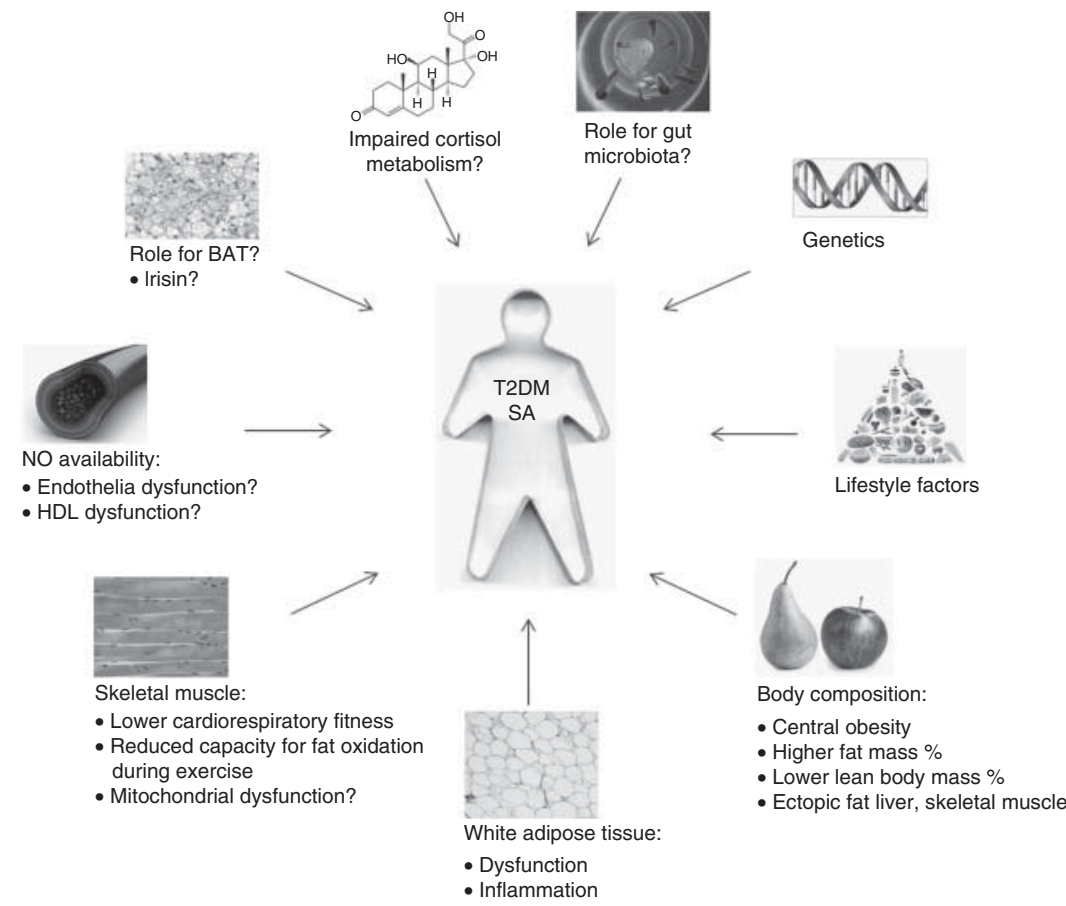

Figure 2 Potential pathophysiological mechanisms that may underlie or contribute to the increased risk of T2DM in South Asians compared with White Caucasians. 
Differences in dietary habits do not seem to play an important role in the increased diabetes risk. The number of studies examining the effects of exercise is small but consistently show - self-reported - lower daily activity levels and lower cardiorespiratory fitness (maximal oxygen uptake $\mathrm{VO}_{2 \max }$ ) in South Asians, which appears to contribute to the increased level of IR. Further research should focus not only on duration and intensity of physical activity and exercise (endurance vs strength) but also on the underlying cellular mechanisms.

We think there are several other areas of interest that should be explored in South Asians to further investigate the increased risk for IR and T2DM. Firstly, brown adipose tissue (BAT): BAT burns TG and glucose to generate heat through a process called mitochondrial uncoupling (169). As BAT is involved in around 20\% of total energy expenditure (170) and clearance of serum TG and glucose, it could play a role in the disturbed metabolic phenotype of South Asians. Secondly, and in light of the interest in BAT, is irisin: irisin is a recently discovered myokine that increases with exercise and is, at least in rodents, involved in browning of white adipose tissue (171). Given the fact that South Asians have lower muscle mass and lower physical activity levels, the role of irisin in IR and the amount of BAT should be further explored. Thirdly, the gut microbiota of South Asians might be quite different from White Caucasians. The gut microbiota of obese subjects appears to be different from that of lean subjects and is thought to be associated with IR (172). Fourthly, the thin-fat phenotype might suggest differences in the hypothalamic-pituitary-adrenal axis with (tissuespecific) impaired cortisol metabolism.

As for now, we conclude that the strong genetic predisposition for T2DM in South Asians should be explained by as of yet undiscovered polymorphisms that negatively interact with environmental factors such as Western-type diet and low level of physical activity. In addition, genetic makeup accounts for the disadvantageous body composition with low muscle mass and increased visceral fat mass. The ensuing effects on the release of proinflammatory adipocytokines, myokines, and FFAs disrupt cellular processes and induce IR.

\section{Supplementary data}

This is linked to the online version of the paper at http://dx.doi.org/ 10.1530/EJE-13-0307.

\section{Declaration of interest}

The authors declare that there is no conflict of interest that could be perceived as prejudicing the impartiality of the review reported.

\section{Funding}

This study was funded by an unrestricted grant of Roba Metals BV (IJsselstein, The Netherlands).

\section{Author contribution statement}

L E H Bakker and M A Sleddering contributed to the literature search, literature selection, and manuscript writing. J W Schoones contributed to the literature search and literature selection. A E Meinders and I M Jazet contributed to the literature selection and reviewed/edited the manuscript.

\section{References}

1 Shaw JE, Sicree RA \& Zimmet PZ. Global estimates of the prevalence of diabetes for 2010 and 2030. Diabetes Research and Clinical Practice 201087 4-14. (doi:10.1016/j.diabres.2009. 10.007)

2 Anjana RM, Pradeepa R, Deepa M, Datta M, Sudha V, Unnikrishnan R, Bhansali A, Joshi SR, Joshi PP, Yajnik CS et al. Prevalence of diabetes and prediabetes (impaired fasting glucose and/or impaired glucose tolerance) in urban and rural India: phase I results of the Indian Council of Medical ResearchINdia DIABetes (ICMR-INDIAB) study. Diabetologia $20115 \mathbf{5 4}$ 3022-3027. (doi:10.1007/s00125-011-2291-5)

3 Katikireddi SV, Morling JR \& Bhopal R. Is there a divergence in time trends in the prevalence of impaired glucose tolerance and diabetes? A systematic review in South Asian populations. International Journal of Epidemiology $2011 \quad 40$ 1542-1553. (doi:10.1093/ije/dyr159)

4 Gupta R \& Misra A. Review: type 2 diabetes in India: regional disparities. British Journal of Diabetes $\mathcal{E}$ Vascular Disease $2007 \mathbf{7}$ 12-16. (doi:10.1177/14746514070070010301)

5 Anand SS, Yusuf S, Vuksan V, Devanesen S, Teo KK, Montague PA, Kelemen L, Yi C, Lonn E, Gerstein $\mathrm{H}$ et al. Differences in risk factors, atherosclerosis, and cardiovascular disease between ethnic groups in Canada: the Study of Health Assessment and Risk in Ethnic groups (SHARE). Lancet 2000 356 279-284. (doi:10.1016/S0140-6736(00)02502-2)

6 Mohanty SA, Woolhandler S, Himmelstein DU \& Bor DH. Diabetes and cardiovascular disease among Asian Indians in the United States. Journal of General Internal Medicine 200520 474-478. (doi:10.1111/j.1525-1497.2005.40294.x)

7 DECODE Study Group. Age- and sex-specific prevalences of diabetes and impaired glucose regulation in 13 European cohorts. Diabetes Care 200326 61-69. (doi:10.2337/diacare. 26.1.61)

8 Barnett AH, Dixon AN, Bellary S, Hanif MW, O'Hare JP, Raymond NT \& Kumar S. Type 2 diabetes and cardiovascular risk in the UK South Asian community. Diabetologia 200649 2234-2246. (doi:10.1007/s00125-006-0325-1)

9 Middelkoop BJ, Kesarlal-Sadhoeram SM, Ramsaransing GN \& Struben HW. Diabetes mellitus among South Asian inhabitants of The Hague: high prevalence and an age-specific socioeconomic gradient. International Journal of Epidemiology 199928 1119-1123. (doi:10.1093/ije/28.6.1119)

10 Bindraban NR, van Valkengoed IG, Mairuhu G, Holleman F, Hoekstra JB, Michels BP, Koopmans RP \& Stronks K. Prevalence of diabetes mellitus and the performance of a risk score among Hindustani Surinamese, African Surinamese and ethnic Dutch: a cross-sectional population-based study. BMC Public Health 20088 271. (doi:10.1186/1471-2458-8-271)

11 Chandie Shaw PK, Baboe F, van Es LA, van der Vijver JC, van de Ree MA, de Jonge N \& Rabelink TJ. South-Asian type 2 diabetic patients have higher incidence and faster progression of renal disease compared with Dutch-European diabetic patients. Diabetes Care 200629 1383-1385. (doi:10.2337/dc06-0003)

12 Chandie Shaw PK, Vandenbroucke JP, Tjandra YI, Rosendaal FR, Rosman JB, Geerlings W, de Charro FT \& van Es LA. Increased end-stage diabetic nephropathy in Indo-Asian immigrants living in the Netherlands. Diabetologia 200245 337-341. (doi:10.1007/s00125-001-0758-5) 
13 Mather HM, Chaturvedi N \& Kehely AM. Comparison of prevalence and risk factors for microalbuminuria in South Asians and Europeans with type 2 diabetes mellitus. Diabetic Medicine 199815 672-677. (doi:10.1002/(SICI)1096-9136 (199808) 15:8 < 672::AID-DIA648> 3.0.CO;2-3)

14 DeFronzo RA. Lilly lecture 1987 . The triumvirate: $\beta$-cell, muscle, liver. A collusion responsible for NIDDM. Diabetes 198837 667-687.

15 UK Prospective Diabetes Study Group 1994. UK Prospective Diabetes Study XII: differences between Asian, Afro-Caribbean and white Caucasian type 2 diabetic patients at diagnosis of diabetes. UK Prospective Diabetes Study Group. Diabetic Medicine 199411 670-677. (doi:10.1111/j.1464-5491.1994.tb00331.x)

16 Banerji MA, Faridi N, Atluri R, Chaiken RL \& Lebovitz HE. Body composition, visceral fat, leptin, and insulin resistance in Asian Indian men. Journal of Clinical Endocrinology and Metabolism 1999 84 137-144. (doi:10.1210/jc.84.1.137)

17 Dickinson S, Colagiuri S, Faramus E, Petocz P \& Brand-Miller JC. Postprandial hyperglycemia and insulin sensitivity differ among lean young adults of different ethnicities. Journal of Nutrition $20021322574-2579$.

18 Liew CF, Seah ES, Yeo KP, Lee KO \& Wise SD. Lean, nondiabetic Asian Indians have decreased insulin sensitivity and insulin clearance, and raised leptin compared to Caucasians and Chinese subjects. International Journal of Obesity and Related Metabolic Disorders 200327 784-789. (doi:10.1038/sj.ijo.0802307)

19 McKeigue PM, Marmot MG, Syndercombe Court YD, Cottier DE, Rahman S \& Riemersma RA. Diabetes, hyperinsulinaemia, and coronary risk factors in Bangladeshis in east London. British Heart Journal 198860 390-396. (doi:10.1136/hrt.60.5.390)

20 McKeigue PM, Shah B \& Marmot MG. Relation of central obesity and insulin resistance with high diabetes prevalence and cardiovascular risk in South Asians. Lancet 1991337 382-386. (doi:10.1016/0140-6736(91)91164-P)

21 Nair KS, Bigelow ML, Asmann YW, Chow LS, CoenenSchimke JM, Klaus KA, Guo ZK, Sreekumar R \& Irving BA. Asian Indians have enhanced skeletal muscle mitochondrial capacity to produce ATP in association with severe insulin resistance. Diabetes 200857 1166-1175. (doi:10.2337/db071556)

22 Petersen KF, Dufour S, Feng J, Befroy D, Dziura J, Dalla MC, Cobelli C \& Shulman GI. Increased prevalence of insulin resistance and nonalcoholic fatty liver disease in Asian-Indian men. PNAS 2006103 18273-18277. (doi:10.1073/pnas. 0608537103)

23 Raji A, Seely EW, Arky RA \& Simonson DC. Body fat distribution and insulin resistance in healthy Asian Indians and Caucasians. Journal of Clinical Endocrinology and Metabolism 200186 5366-5371. (doi:10.1210/jc.86.11.5366)

24 Raji A, Gerhard-Herman MD, Warren M, Silverman SG, Raptopoulos V, Mantzoros CS \& Simonson DC. Insulin resistance and vascular dysfunction in nondiabetic Asian Indians. Journal of Clinical Endocrinology and Metabolism 200489 3965-3972. (doi:10.1210/jc.2004-0087)

25 Raji A, Gerhard-Herman MD, Williams JS, O'Connor ME \& Simonson DC. Effect of pioglitazone on insulin sensitivity, vascular function and cardiovascular inflammatory markers in insulin-resistant non-diabetic Asian Indians. Diabetic Medicine 200623 537-543. (doi:10.1111/j.1464-5491.2006.01843.x)

26 Boon MR, Karamali NS, de Groot CJ, van Steijn L, Kanhai HH, van der Bent C, Berbee JF, Middelkoop B, Rensen PC \& Tamsma JT. E-selectin is elevated in cord blood of South Asian neonates compared with Caucasian neonates. Journal of Pediatrics 2012 160 844-848. (doi:10.1016/j.jpeds.2011.11.025)

27 Yajnik CS, Lubree HG, Rege SS, Naik SS, Deshpande JA, Deshpande SS, Joglekar CV \& Yudkin JS. Adiposity and hyperinsulinemia in Indians are present at birth. Journal of Clinical Endocrinology and Metabolism 200287 5575-5580. (doi:10.1210/jc.2002-020434)

28 Whincup PH, Gilg JA, Papacosta O, Seymour C, Miller GJ, Alberti KG \& Cook DG. Early evidence of ethnic differences in cardiovascular risk: cross sectional comparison of British South Asian and white children. BMJ $2002 \mathbf{3 2 4} 635$. (doi:10.1136/ bmj.324.7338.635)

29 Lakshmi S, Metcalf B, Joglekar C, Yajnik CS, Fall CH \& Wilkin TJ. Differences in body composition and metabolic status between white U.K. and Asian Indian children (EarlyBird 24 and the Pune Maternal Nutrition Study). Pediatric Obesity 20127 347-354. (doi:10.1111/j.2047-6310.2012.00063.x)

30 Whincup PH, Gilg JA, Owen CG, Odoki K, Alberti KG \& Cook DG. British South Asians aged 13-16 years have higher fasting glucose and insulin levels than Europeans. Diabetic Medicine 200522 1275-1277. (doi:10.1111/j.1464-5491. 2005.01587.x)

31 Cruz ML, Evans K \& Frayn KN. Postprandial lipid metabolism and insulin sensitivity in young Northern Europeans, South Asians and Latin Americans in the UK. Atherosclerosis 2001159 441-449. (doi:10.1016/S0021-9150(01)00523-8)

32 Laws A, Jeppesen JL, Maheux PC, Schaaf P, Chen YD \& Reaven GM. Resistance to insulin-stimulated glucose uptake and dyslipidemia in Asian Indians. Arteriosclerosis and Thrombosis 199414 917-922. (doi:10.1161/01.ATV.14.6.917)

33 Chandalia M, Abate N, Garg A, Stray-Gundersen J \& Grundy SM. Relationship between generalized and upper body obesity to insulin resistance in Asian Indian men. Journal of Clinical Endocrinology and Metabolism $1999 \mathbf{8 4}$ 2329-2335. (doi:10.1210/ jc.84.7.2329)

34 Chandalia M, Lin P, Seenivasan T, Livingston EH, Snell PG, Grundy SM \& Abate N. Insulin resistance and body fat distribution in South Asian men compared to Caucasian men. PLoS ONE 20072 e812. (doi:10.1371/journal.pone.0000812)

35 Sharp PS, Mohan V, Levy JC, Mather HM \& Kohner EM. Insulin resistance in patients of Asian Indian and European origin with non-insulin dependent diabetes. Hormone and Metabolic Research 198719 84-85. (doi:10.1055/s-2007-1011745)

36 Munoz A, Abate N \& Chandalia M. Adipose tissue collagen and inflammation in nonobese Asian Indian men. Journal of Clinical Endocrinology and Metabolism 201398 E1360-E1363. (doi:10.1210/jc.2012-3841)

37 Lillioja S, Mott DM, Howard BV, Bennett PH, Yki-Jarvinen H, Freymond D, Nyomba BL, Zurlo F, Swinburn B \& Bogardus C. Impaired glucose tolerance as a disorder of insulin action. Longitudinal and cross-sectional studies in Pima Indians. New England Journal of Medicine $1988 \mathbf{3 1 8} 1217-1225$. (doi:10.1056/NEJM198805123181901)

38 Lillioja S, Mott DM, Spraul M, Ferraro R, Foley JE, Ravussin E, Knowler WC, Bennett PH \& Bogardus C. Insulin resistance and insulin secretory dysfunction as precursors of noninsulin-dependent diabetes mellitus. Prospective studies of Pima Indians. New England Journal of Medicine 1993329 1988-1992. (doi:10.1056/NEJM199312303292703)

39 Gelding SV, Andres C, Niththyananthan R, Gray IP, Mather H \& Johnston DG. Increased secretion of 32,33 split proinsulin after intravenous glucose in glucose-tolerant first-degree relatives of patients with non-insulin dependent diabetes of European, but not Asian, origin. Clinical Endocrinology 199542 255-264. (doi:10.1111/j.1365-2265.1995.tb01873.x)

40 Snehalatha C, Satyavani K, Sivasankari S, Vijay V \& Ramachandran A. Insulin secretion and action in different stages of glucose tolerance in Asian Indians. Diabetic Medicine 199916 408-414. (doi:10.1046/j.1464-5491.1999.00084.x)

41 Matsumoto K, Miyake S, Yano M, Ueki Y, Yamaguchi Y, Akazawa S \& Tominaga Y. Glucose tolerance, insulin secretion, and insulin sensitivity in nonobese and obese Japanese subjects. Diabetes Care 199720 1562-1568. (doi:10.2337/diacare.20. 10.1562)

42 Yoneda H, Ikegami H, Yamamoto Y, Yamato E, Cha T, Kawaguchi Y, Tahara Y \& Ogihara T. Analysis of early-phase insulin responses in nonobese subjects with mild glucose intolerance. Diabetes Care 199215 1517-1521. (doi:10.2337/ diacare.15.11.1517) 
43 Neel JV. Diabetes mellitus: a "thrifty" genotype rendered detrimental by "progress"? American Journal of Human Genetics $196214353-362$.

44 Sniderman AD, Bhopal R, Prabhakaran D, Sarrafzadegan N \& Tchernof A. Why might South Asians be so susceptible to central obesity and its atherogenic consequences? The adipose tissue overflow hypothesis. International Journal of Epidemiology 2007 36 220-225. (doi:10.1093/ije/dyl245)

45 Wells JC. Commentary: why are South Asians susceptible to central obesity? - the El Nino hypothesis. International Journal of Epidemiology 200736 226-227. (doi:10.1093/ije/dyl287)

46 Wells JC. Ethnic variability in adiposity and cardiovascular risk: the variable disease selection hypothesis. International Journal of Epidemiology 200938 63-71. (doi:10.1093/ije/dyn183)

47 Bhopal RS \& Rafnsson SB. Could mitochondrial efficiency explain the susceptibility to adiposity, metabolic syndrome, diabetes and cardiovascular diseases in South Asian populations? International Journal of Epidemiology 200938 1072-1081. (doi:10.1093/ije/ dyp202)

48 Hales CN \& Barker DJ. Type 2 (non-insulin-dependent) diabetes mellitus: the thrifty phenotype hypothesis. Diabetologia 199235 595-601. (doi:10.1007/BF00400248)

49 Hales CN \& Barker DJ. The thrifty phenotype hypothesis. British Medical Bulletin 200160 5-20. (doi:10.1093/bmb/60.1.5)

50 Whincup PH, Kaye SJ, Owen CG, Huxley R, Cook DG, Anazawa S, Barrett-Connor E, Bhargava SK, Birgisdottir BE, Carlsson S et al. Birth weight and risk of type 2 diabetes: a systematic review. Journal of the American Medical Association 20083002886 2897. (doi:10.1001/jama.2008.886)

51 Harding S, Rosato MG \& Cruickshank JK. Lack of change in birthweights of infants by generational status among Indian, Pakistani, Bangladeshi, Black Caribbean, and Black African mothers in a British cohort study. International Journal of Epidemiology 200433 1279-1285. (doi:10.1093/ije/dyh186)

52 Norris SA, Osmond C, Gigante D, Kuzawa CW, Ramakrishnan L, Lee NR, Ramirez-Zea M, Richter LM, Stein AD, Tandon N et al. Size at birth, weight gain in infancy and childhood, and adult diabetes risk in five low- or middle-income country birth cohorts. Diabetes Care 201235 72-79. (doi:10.2337/dc11-0456)

53 Rueda-Clausen CF, Dolinsky VW, Morton JS, Proctor SD, Dyck JR \& Davidge ST. Hypoxia-induced intrauterine growth restriction increases the susceptibility of rats to high-fat diet-induced metabolic syndrome. Diabetes 201160 507-516. (doi:10.2337/ db10-1239)

54 Radha V \& Mohan V. Genetic predisposition to type 2 diabetes among Asian Indians. Indian Journal of Medical Research 2007 $125259-274$.

55 McCarthy MI. Genomics, type 2 diabetes, and obesity. New England Journal of Medicine 2010363 2339-2350. (doi:10.1056/ NEJMra0906948)

56 Kooner JS, Saleheen D, Sim X, Sehmi J, Zhang W, Frossard P, Been LF, Chia KS, Dimas AS, Hassanali N et al. Genome-wide association study in individuals of South Asian ancestry identifies six new type 2 diabetes susceptibility loci. Nature Genetics 2011 43 984-989. (doi:10.1038/ng.921)

57 Rees SD, Hydrie MZ, Shera AS, Kumar S, O'Hare JP, Barnett AH, Basit A \& Kelly MA. Replication of 13 genome-wide association (GWA)-validated risk variants for type 2 diabetes in Pakistani populations. Diabetologia 201154 1368-1374. (doi:10.1007/ s00125-011-2063-2)

58 Chauhan G, Spurgeon CJ, Tabassum R, Bhaskar S, Kulkarni SR, Mahajan A, Chavali S, Kumar MV, Prakash S, Dwivedi OP et al. Impact of common variants of PPARG, KCNJ11, TCF7L2, SLC30A8, HHEX, CDKN2A, IGF2BP2, and CDKAL1 on the risk of type 2 diabetes in 5,164 Indians. Diabetes $2010 \mathbf{5 9}$ 2068-2074. (doi:10.2337/db09-1386)

59 Radha V, Vimaleswaran KS, Babu HN, Abate N, Chandalia M, Satija P, Grundy SM, Ghosh S, Majumder PP, Deepa R et al. Role of genetic polymorphism peroxisome proliferator-activated receptor- $\gamma 2$ Pro12Ala on ethnic susceptibility to diabetes in South-Asian and Caucasian subjects: evidence for heterogeneity. Diabetes Care 200629 1046-1051. (doi:10.2337/dc05-1473)

60 Sanghera DK, Demirci FY, Been L, Ortega L, Ralhan S, Wander GS, Mehra NK, Singh J, Aston CE, Mulvihill JJ et al. PPARG and DIPOQ gene polymorphisms increase type 2 diabetes mellitus risk in Asian Indian Sikhs: Pro12Ala still remains as the strongest predictor. Metabolism $2010 \quad 59$ 492-501. (doi:10.1016/j.metabol.2009.07.043)

61 Sanghera DK, Ortega L, Han S, Singh J, Ralhan SK, Wander GS, Mehra NK, Mulvihill JJ, Ferrell RE, Nath SK et al. Impact of nine common type 2 diabetes risk polymorphisms in Asian Indian Sikhs: PPARG2 (Pro12Ala), IGF2BP2, TCF7L2 and FTO variants confer a significant risk. BMC Medical Genetics 2008959. (doi:10.1186/1471-2350-9-59)

62 Li H, Kilpelainen TO, Liu C, Zhu J, Liu Y, Hu C, Yang Z, Zhang W, Bao W, Cha $\mathrm{S}$ et al. Association of genetic variation in FTO with risk of obesity and type 2 diabetes with data from 96,551 East and South Asians. Diabetologia $2012 \quad 55$ 981-995. (doi:10.1007/s00125-011-2370-7)

63 Yajnik CS, Janipalli CS, Bhaskar S, Kulkarni SR, Freathy RM, Prakash S, Mani KR, Weedon MN, Kale SD, Deshpande J et al. FTO gene variants are strongly associated with type 2 diabetes in South Asian Indians. Diabetologia 200952 247-252. (doi:10.1007/s00125-008-1186-6)

64 Ramya K, Radha V, Ghosh S, Majumder PP \& Mohan V. Genetic variations in the FTO gene are associated with type 2 diabetes and obesity in South Indians (CURES-79). Diabetes Technology $\mathcal{E}$ Therapeutics 201113 33-42. (doi:10.1089/dia.2010.0071)

65 Chauhan G, Tabassum R, Mahajan A, Dwivedi OP, Mahendran Y, Kaur I, Nigam S, Dubey H, Varma B, Madhu SV et al. Common variants of FTO and the risk of obesity and type 2 diabetes in Indians. Journal of Human Genetics 201156 720-726. (doi:10.1038/jhg.2011.87)

66 Bhatt SP, Nigam P, Misra A, Guleria R, Luthra K, Jain SK \& Qadar Pasha MA. Association of the myostatin gene with obesity, abdominal obesity and low lean body mass and in non-diabetic Asian Indians in north India. PLoS ONE 20127 e40977. (doi:10.1371/journal.pone.0040977)

67 Saxena R, Saleheen D, Been LF, Garavito ML, Braun T, Bjonnes A, Young R, Ho WK, Rasheed A, Frossard P et al. Genome-wide association study identifies a novel locus contributing to type 2 diabetes susceptibility in Sikhs of Punjabi origin from India. Diabetes 201362 1746-1755. (doi:10.2337/db12-1077)

68 Garduno-Diaz SD \& Khokhar S. Prevalence, risk factors and complications associated with type 2 diabetes in migrant South Asians. Diabetes/Metabolism Research and Reviews 201228 6-24. (doi:10.1002/dmrr.1219)

69 Lovegrove JA, Lovegrove SS, Lesauvage SV, Brady LM, Saini N, Minihane AM \& Williams CM. Moderate fish-oil supplementation reverses low-platelet, long-chain n-3 polyunsaturated fatty acid status and reduces plasma triacylglycerol concentrations in British Indo-Asians. American Journal of Clinical Nutrition 2004 79 974-982.

70 McKeigue PM, Marmot MG, Adelstein AM, Hunt SP, Shipley MJ, Butler SM, Riemersma RA \& Turner PR. Diet and risk factors for coronary heart disease in Asians in Northwest London. Lancet 19852 1086-1090. (doi:10.1016/S0140-6736(85)90684-1)

71 Miller GJ, Kotecha S, Wilkinson WH, Wilkes H, Stirling Y, Sanders TA, Broadhurst A, Allison J \& Meade TW. Dietary and other characteristics relevant for coronary heart disease in men of Indian, West Indian and European descent in London. Atherosclerosis 198870 63-72. (doi:10.1016/0021-9150(88) 90100-1)

72 Misra A, Khurana L, Isharwal S \& Bhardwaj S. South Asian diets and insulin resistance. British Journal of Nutrition $2009 \mathbf{1 0 1}$ 465-473. (doi:10.1017/S0007114508073649)

73 Sevak L, McKeigue PM \& Marmot MG. Relationship of hyperinsulinemia to dietary intake in South Asian and European men. American Journal of Clinical Nutrition 199459 1069-1074. 
74 Donin AS, Nightingale CM, Owen CG, Rudnicka AR, McNamara MC, Prynne CJ, Stephen AM, Cook DG \& Whincup PH. Nutritional composition of the diets of South Asian, black African-Caribbean and white European children in the United Kingdom: the Child Heart and Health Study in England (CHASE). British Journal of Nutrition $2010 \mathbf{1 0 4}$ 276-285. (doi:10.1017/S000711451000070X)

75 Isharwal S, Arya S, Misra A, Wasir JS, Pandey RM, Rastogi K, Vikram NK, Luthra K \& Sharma R. Dietary nutrients and insulin resistance in urban Asian Indian adolescents and young adults. Annals of Nutrition \& Metabolism 200852 145-151. (doi:10.1159/000127416)

76 Brady LM, Lovegrove SS, Lesauvage SV, Gower BA, Minihane AM, Williams CM \& Lovegrove JA. Increased n-6 polyunsaturated fatty acids do not attenuate the effects of long-chain n-3 polyunsaturated fatty acids on insulin sensitivity or triacylglycerol reduction in Indian Asians. American Journal of Clinical Nutrition 200479 983-991.

77 Becker E, Boreham R, Chaudhury M, Craig R, Deverill C, Doyle M, Erens B, Falaschetti E, Fuller E, Hills A et al. Health Survey for England - 2004: The health of minority ethnic groups, vol 1. The Information Centre, 2006.

78 Bowen L, Ebrahim S, De Stavola B, Ness A, Kinra S, Bharathi AV, Prabhakaran D \& Reddy KS. Dietary intake and rural-urban migration in India: a cross-sectional study. PLoS ONE 20116 e14822. (doi:10.1371/journal.pone.0014822)

79 Leung G \& Stanner S. Diets of minority ethnic groups in the UK: influence on chronic disease risk and implications for prevention. Nutrition Bulletin 201136 161-198. (doi:10.1111/j.14673010.2011.01889.x)

80 Simmons D, Williams DR \& Powell MJ. Prevalence of diabetes in different regional and religious South Asian communities in Coventry. Diabetic Medicine 19929 428-431. (doi:10.1111/ j.1464-5491.1992.tb01812.x)

81 Simmons D \& Williams R. Dietary practices among Europeans and different South Asian groups in Coventry. British Journal of Nutrition 199778 5-14. (doi:10.1079/BJN19970114)

82 Admiraal WM, van Valkengoed IG, L de Munter JS, Stronks K, Hoekstra JB \& Holleman F. The association of physical inactivity with type 2 diabetes among different ethnic groups. Diabetic Medicine 201128 668-672. (doi:10.1111/j.1464-5491.2011. 03248.x)

83 Dhawan J \& Bray CL. Asian Indians, coronary artery disease, and physical exercise. Heart $1997 \mathbf{7 8}$ 550-554. (doi:10.1136/hrt. 78.6.550)

84 Fischbacher CM, Bhopal R, Unwin N, Walker M, White M \& Alberti KG. Maternal transmission of type 2 diabetes varies by ethnic group: cross-sectional survey of Europeans and South Asians. Diabetes Care 200124 1685-1686. (doi:10.2337/ diacare.24.9.1685-a)

85 Fischbacher CM, Hunt S \& Alexander L. How physically active are South Asians in the United Kingdom? A literature review. Journal of Public Health 200426 250-258. (doi:10.1093/ pubmed/fdh158)

86 Hayes L, White M, Unwin N, Bhopal R, Fischbacher C, Harland J \& Alberti KG. Patterns of physical activity and relationship with risk markers for cardiovascular disease and diabetes in Indian, Pakistani, Bangladeshi and European adults in a UK population. Journal of Public Health Medicine 200224 170-178. (doi:10.1093/pubmed/24.3.170)

87 Lean ME, Han TS, Bush H, Anderson AS, Bradby H \& Williams R. Ethnic differences in anthropometric and lifestyle measures related to coronary heart disease risk between South Asian, Italian and general-population British women living in the west of Scotland. International Journal of Obesity and Related Metabolic Disorders 200125 1800-1805. (doi:10.1038/sj.ijo.0801823)

88 Bettiol H, Rona RJ \& Chinn S. Variation in physical fitness between ethnic groups in nine year olds. International Journal of Epidemiology 199928 281-286. (doi:10.1093/ije/28.2.281)
89 Hardy CP \& Eston RG. Aerobic fitness of Anglo-Saxon and Indian students. British Journal of Sports Medicine $198519217-218$. (doi:10.1136/bjsm.19.4.217)

90 Owen CG, Nightingale CM, Rudnicka AR, Cook DG, Ekelund U \& Whincup PH. Ethnic and gender differences in physical activity levels among 9-10-year-old children of white European, South Asian and African-Caribbean origin: the Child Heart Health Study in England (CHASE Study). International Journal of Epidemiology 200938 1082-1093. (doi:10.1093/ije/dyp176)

91 Williams R \& Shams M. Generational continuity and change in British Asian health and health behaviour. Journal of Epidemiology and Community Health 199852 558-563. (doi:10.1136/jech. 52.9.558)

92 Chiu M, Austin PC, Manuel DG, Shah BR \& Tu JV. Deriving ethnic-specific BMI cutoff points for assessing diabetes risk. Diabetes Care 201134 1741-1748. (doi:10.2337/dc10-2300)

93 Gray LJ, Yates T, Davies MJ, Brady E, Webb DR, Sattar N \& Khunti K. Defining obesity cut-off points for migrant South Asians. PLoS ONE 20116 e26464. (doi:10.1371/journal.pone. 0026464)

94 Nightingale CM, Rudnicka AR, Owen CG, Wells JC, Sattar N, Cook DG \& Whincup PH. Influence of adiposity on insulin resistance and glycemia markers among U.K. children of South Asian, black African-Caribbean, and white European origin: child heart and health study in England. Diabetes Care 201336 1712-1719. (doi:10.2337/dc12-1726)

95 Rush EC, Freitas I \& Plank LD. Body size, body composition and fat distribution: comparative analysis of European, Maori, Pacific Island and Asian Indian adults. British Journal of Nutrition 2009 102 632-641. (doi:10.1017/S0007114508207221)

96 Lear SA, Humphries KH, Kohli S, Chockalingam A, Frohlich JJ \& Birmingham CL. Visceral adipose tissue accumulation differs according to ethnic background: results of the Multicultural Community Health Assessment Trial (M-CHAT). American Journal of Clinical Nutrition 200786 353-359.

97 Ghouri N, Purves D, McConnachie A, Wilson J, Gill JM \& Sattar N. Lower cardiorespiratory fitness contributes to increased insulin resistance and fasting glycaemia in middle-aged South Asian compared with European men living in the UK. Diabetologia 2013. In press. (doi:10.1007/s00125-013-2969-y)

98 Nightingale CM, Rudnicka AR, Owen CG, Cook DG \& Whincup PH. Patterns of body size and adiposity among UK children of South Asian, black African-Caribbean and white European origin: Child Heart And health Study in England (CHASE Study). International Journal of Epidemiology $2011 \mathbf{4 0}$ 33-44. (doi:10.1093/ije/dyq180)

99 Ehtisham S, Crabtree N, Clark P, Shaw N \& Barrett T. Ethnic differences in insulin resistance and body composition in United Kingdom adolescents. Journal of Clinical Endocrinology and Metabolism 200590 3963-3969. (doi:10.1210/jc.2004-2001)

100 Stanfield KM, Wells JC, Fewtrell MS, Frost C \& Leon DA. Differences in body composition between infants of South Asian and European ancestry: the London Mother and Baby Study. International Journal of Epidemiology 201241 1409-1418. (doi:10.1093/ije/dys139)

101 Yajnik CS, Fall CH, Coyaji KJ, Hirve SS, Rao S, Barker DJ, Joglekar C \& Kellingray S. Neonatal anthropometry: the thin-fat Indian baby. The Pune Maternal Nutrition Study. International Journal of Obesity and Related Metabolic Disorders 200327 173-180. (doi:10.1038/sj.ijo.802219)

102 Krishnaveni GV, Hill JC, Veena SR, Leary SD, Saperia J, Chachyamma KJ, Karat SC \& Fall CH. Truncal adiposity is present at birth and in early childhood in South Indian children. Indian Pediatrics 200542 527-538.

103 van Steijn L, Karamali NS, Kanhai HHH, Ariens GAM, Fall CHD, Yajnik CS, Middelkoop BJC \& Tamsma JT. Neonatal anthropometry: thin-fat phenotype in fourth to fifth generation South Asian neonates in Surinam. International Journal of Obesity 2009 33 1326-1329. (doi:10.1038/ijo.2009.154)

104 Modi N, Thomas EL, Uthaya SN, Umranikar S, Bell JD \& Yajnik C. Whole body magnetic resonance imaging of healthy newborn 
infants demonstrates increased central adiposity in Asian Indians. Pediatric Research 200965 584-587. (doi:10.1203/ PDR.0b013e31819d98be)

105 Anjana M, Sandeep S, Deepa R, Vimaleswaran KS, Farooq S \& Mohan V. Visceral and central abdominal fat and anthropometry in relation to diabetes in Asian Indians. Diabetes Care 200427 2948-2953. (doi:10.2337/diacare.27.12.2948)

106 Indulekha K, Anjana RM, Surendar J \& Mohan V. Association of visceral and subcutaneous fat with glucose intolerance, insulin resistance, adipocytokines and inflammatory markers in Asian Indians (CURES-113). Clinical Biochemistry 201144 281-287. (doi:10.1016/j.clinbiochem.2010.12.015)

107 Sandeep S, Gokulakrishnan K, Velmurugan K, Deepa M \& Mohan V. Visceral \& subcutaneous abdominal fat in relation to insulin resistance \& metabolic syndrome in non-diabetic South Indians. Indian Journal of Medical Research 2010131 629-635.

108 Goel K, Misra A, Vikram NK, Poddar P \& Gupta N. Subcutaneous abdominal adipose tissue is associated with the metabolic syndrome in Asian Indians independent of intra-abdominal and total body fat. Heart 201096 579-583. (doi:10.1136/hrt. 2009.183236)

109 Anand SS, Tarnopolsky MA, Rashid S, Schulze KM, Desai D, Mente A, Rao S, Yusuf S, Gerstein HC \& Sharma AM. Adipocyte hypertrophy, fatty liver and metabolic risk factors in South Asians: the Molecular Study of Health and Risk in Ethnic Groups (mol-SHARE). PLoS ONE 20116 e22112. (doi:10.1371/journal. pone.0022112)

110 Kohli S, Sniderman AD, Tchernof A \& Lear SA. Ethnicspecific differences in abdominal subcutaneous adipose tissue compartments. Obesity 201018 2177-2183. (doi:10.1038/oby. 2010.94)

111 Goossens GH. The role of adipose tissue dysfunction in the pathogenesis of obesity-related insulin resistance. Physiology $\mathcal{E}$ Behavior 200894 206-218. (doi:10.1016/j.physbeh.2007. 10.010)

112 Lundgren M, Svensson M, Lindmark S, Renström F, Ruge T \& Eriksson JW. Fat cell enlargement is an independent marker of insulin resistance and 'hyperleptinaemia'. Diabetologia $2007 \mathbf{5 0}$ 625-633. (doi:10.1007/s00125-006-0572-1)

113 Weyer C, Foley JE, Bogardus C, Tataranni PA \& Pratley RE. Enlarged subcutaneous abdominal adipocyte size, but not obesity itself, predicts type II diabetes independent of insulin resistance. Diabetologia 200043 1498-1506. (doi:10.1007/ s001250051560)

114 Balakrishnan P, Grundy SM, Islam A, Dunn F \& Vega GL. Influence of upper and lower body adipose tissue on insulin sensitivity in South Asian men. Journal of Investigative Medicine 201260 999-1004. (doi:10.231/JIM.0b013e3182650a09)

115 Abate N, Chandalia M, Snell PG \& Grundy SM. Adipose tissue metabolites and insulin resistance in nondiabetic Asian Indian men. Journal of Clinical Endocrinology and Metabolism 200489 2750-2755. (doi:10.1210/jc.2003-031843)

116 Jazet IM, Pijl H \& Meinders AE. Adipose tissue as an endocrine organ: impact on insulin resistance. Netherlands Journal of Medicine 200361 194-212.

117 Kalhan R, Puthawala K, Agarwal S, Amini SB \& Kalhan SC. Altered lipid profile, leptin, insulin, and anthropometry in offspring of South Asian immigrants in the United States. Metabolism 200150 1197-1202. (doi:10.1053/meta.2001. 26704)

118 Lilja M, Rolandsson O, Shaw JE, Pauvaday V, Cameron AJ, Tuomilehto J, Alberti KG, Zimmet PZ \& Soderberg S. Higher leptin levels in Asian Indians than Creoles and Europids: a potential explanation for increased metabolic risk. International Journal of Obesity 201034 878-885. (doi:10.1038/ijo.2010.19)

119 Mente A, Razak F, Blankenberg S, Vuksan V, Davis AD, Miller R, Teo K, Gerstein H, Sharma AM, Yusuf S et al. Ethnic variation in adiponectin and leptin levels and their association with adiposity and insulin resistance. Diabetes Care 201033 1629-1634. (doi:10.2337/dc09-1392)
120 Ramachandran A, Snehalatha C, Vijay V, Satyavani K, Latha E \& Haffner SM. Plasma leptin in non-diabetic Asian Indians: association with abdominal adiposity. Diabetic Medicine 199714 937-941. (doi:10.1002/(SICI)1096-9136(199711)14:11<937 ::AID-DIA502>3.0.CO;2-S)

121 Webb DR, Khunti K, Chatterjee S, Jarvis J \& Davies MJ. Adipocytokine associations with insulin resistance in British South Asians. Journal of Diabetes Research 20132013561016. (doi:10.1155/2013/561016)

122 Weyer C, Funahashi T, Tanaka S, Hotta K, Matsuzawa Y, Pratley RE \& Tataranni PA. Hypoadiponectinemia in obesity and type 2 diabetes: close association with insulin resistance and hyperinsulinemia. Journal of Clinical Endocrinology and Metabolism 200186 1930-1935. (doi:10.1210/jc.86.5.1930)

123 Goldstein BJ \& Scalia R. Adiponectin: a novel adipokine linking adipocytes and vascular function. Journal of Clinical Endocrinology and Metabolism 200489 2563-2568. (doi:10.1210/jc.20040518)

124 Valsamakis G, Chetty R, McTernan PG, Al-Daghri NM, Barnett AH \& Kumar S. Fasting serum adiponectin concentration is reduced in Indo-Asian subjects and is related to HDL cholesterol. Diabetes, Obesity \& Metabolism 20035 131-135. (doi:10.1046/j.1463-1326.2003.00254.x)

125 Bansal N, Anderson SG, Vyas A, Gemmell I, Charlton-Menys V, Oldroyd J, Pemberton P, Durrington PN, Clayton PE \& Cruickshank JK. Adiponectin and lipid profiles compared with insulins in relation to early growth of British South Asian and European children: the Manchester children's growth and vascular health study. Journal of Clinical Endocrinology and Metabolism 201196 2567-2574. (doi:10.1210/jc.2011-0046)

126 Wasim H, Al-Daghri NM, Chetty R, McTernan PG, Barnett AH \& Kumar S. Relationship of serum adiponectin and resistin to glucose intolerance and fat topography in South-Asians. Cardiovascular Diabetology 20065 10. (doi:10.1186/1475-2840-5-10)

127 Snehalatha C, Mukesh B, Simon M, Viswanathan V, Haffner SM \& Ramachandran A. Plasma adiponectin is an independent predictor of type 2 diabetes in Asian Indians. Diabetes Care 2003 26 3226-3229. (doi:10.2337/diacare.26.12.3226)

128 Martin M, Palaniappan LP, Kwan AC, Reaven GM \& Reaven PD. Ethnic differences in the relationship between adiponectin and insulin sensitivity in South Asian and Caucasian women. Diabetes Care 200831 798-801. (doi:10.2337/dc07-1781)

129 Donath MY \& Shoelson SE. Type 2 diabetes as an inflammatory disease. Nature Reviews. Immunology 201111 98-107. (doi:10.1038/nri2925)

130 Plomgaard P, Bouzakri K, Krogh-Madsen R, Mittendorfer B, Zierath JR \& Pedersen BK. Tumor necrosis factor- $\alpha$ induces skeletal muscle insulin resistance in healthy human subjects via inhibition of Akt substrate 160 phosphorylation. Diabetes 2005 54 2939-2945. (doi:10.2337/diabetes.54.10.2939)

131 Peters MJ, Ghouri N, McKeigue P, Forouhi NG \& Sattar N. Circulating IL-6 concentrations and associated anthropometric and metabolic parameters in South Asian men and women in comparison to European whites. Cytokine 201361 29-32. (doi:10.1016/j.cyto.2012.09.002)

132 Chambers JC, Eda S, Bassett P, Karim Y, Thompson SG, Gallimore JR, Pepys MB \& Kooner JS. C-reactive protein, insulin resistance, central obesity, and coronary heart disease risk in Indian Asians from the United Kingdom compared with European whites. Circulation $2001 \mathbf{1 0 4} 145-150$. (doi:10.1161/ 01.CIR.104.2.145)

133 Forouhi NG, Sattar N \& McKeigue PM. Relation of C-reactive protein to body fat distribution and features of the metabolic syndrome in Europeans and South Asians. International Journal of Obesity and Related Metabolic Disorders 200125 1327-1331. (doi:10.1038/sj.ijo.0801723)

134 Snel M, Jonker JT, Schoones J, Lamb H, de Roos A, Pijl H, Smit JW, Meinders AE \& Jazet IM. Ectopic fat and insulin resistance: pathophysiology and effect of diet and lifestyle interventions. International Journal of Endocrinology 20122012983814. (doi:10.1155/2012/983814) 
135 Korenblat KM, Fabbrini E, Mohammed BS \& Klein S. Liver, muscle, and adipose tissue insulin action is directly related to intrahepatic triglyceride content in obese subjects. Gastroenterology 2008134 1369-1375. (doi:10.1053/j.gastro.2008.01.075)

136 Seppala-Lindroos A, Vehkavaara S, Hakkinen AM, Goto T, Westerbacka J, Sovijarvi A, Halavaara J \& Yki-Jarvinen $\mathrm{H}$. Fat accumulation in the liver is associated with defects in insulin suppression of glucose production and serum free fatty acids independent of obesity in normal men. Journal of Clinical Endocrinology and Metabolism 200287 3023-3028. (doi:10.1210/jc.87.7.3023)

137 Goodpaster BH, He J, Watkins S \& Kelley DE. Skeletal muscle lipid content and insulin resistance: evidence for a paradox in endurance-trained athletes. Journal of Clinical Endocrinology and Metabolism 200186 5755-5761. (doi:10.1210/jc.86.12.5755)

138 Krssak M, Falk PK, Dresner A, DiPietro L, Vogel SM, Rothman DL, Roden M \& Shulman GI. Intramyocellular lipid concentrations are correlated with insulin sensitivity in humans: a $1 \mathrm{H}$ NMR spectroscopy study. Diabetologia $1999 \quad 42$ 113-116. (doi:10.1007/s001250051123)

139 Jacob S, Machann J, Rett K, Brechtel K, Volk A, Renn W, Maerker E, Matthaei S, Schick F, Claussen CD et al. Association of increased intramyocellular lipid content with insulin resistance in lean nondiabetic offspring of type 2 diabetic subjects. Diabetes 199948 1113-1119. (doi:10.2337/diabetes.48.5.1113)

140 Forouhi NG, Jenkinson G, Thomas EL, Mullick S, Mierisova S, Bhonsle U, McKeigue PM \& Bell JD. Relation of triglyceride stores in skeletal muscle cells to central obesity and insulin sensitivity in European and South Asian men. Diabetologia 1999 42 932-935. (doi:10.1007/s001250051250)

141 Misra A, Sinha S, Kumar M, Jagannathan NR \& Pandey RM. Proton magnetic resonance spectroscopy study of soleus muscle in non-obese healthy and type 2 diabetic Asian Northern Indian males: high intramyocellular lipid content correlates with excess body fat and abdominal obesity. Diabetic Medicine 200320 361-367. (doi:10.1046/j.1464-5491.2003.00932.x)

142 Sinha S, Misra A, Rathi M, Kumar V, Pandey RM, Luthra K \& Jagannathan NR. Proton magnetic resonance spectroscopy and biochemical investigation of type 2 diabetes mellitus in Asian Indians: observation of high muscle lipids and C-reactive protein levels. Magnetic Resonance Imaging 200927 94-100. (doi:10. 1016/j.mri.2008.06.001)

143 Sinha S, Rathi M, Misra A, Kumar V, Kumar M \& Jagannathan NR. Sub-clinical inflammation and soleus muscle intra-myocellular lipids in healthy Asian Indian males. Clinical Endocrinology 200563 350-355. (doi:10.1111/j.1365-2265. 2005.02353.x)

144 DeFronzo RA, Jacot E, Jequier E, Maeder E, Wahren J \& Felber JP. The effect of insulin on the disposal of intravenous glucose. Results from indirect calorimetry and hepatic and femoral venous catheterization. Diabetes $1981301000-1007$.

145 Srikanthan P \& Karlamangla AS. Relative muscle mass is inversely associated with insulin resistance and prediabetes. Findings from the third National Health and Nutrition Examination Survey. Journal of Clinical Endocrinology and Metabolism 201196 2898-2903. (doi:10.1210/jc.2011-0435)

146 Hall LM, Moran CN, Milne GR, Wilson J, MacFarlane NG, Forouhi NG, Hariharan N, Salt IP, Sattar N \& Gill JM. Fat oxidation, fitness and skeletal muscle expression of oxidative/lipid metabolism genes in South Asians: implications for insulin resistance? PLOS ONE 20105 e14197. (doi:10.1371/journal. pone.0014197)

147 Unni US, Ramakrishnan G, Raj T, Kishore RP, Thomas T, Vaz M \& Kurpad AV. Muscle mass and functional correlates of insulin sensitivity in lean young Indian men. European Journal of Clinical Nutrition 200963 1206-1212. (doi:10.1038/ejcn.2009.32)

148 Cline GW, Petersen KF, Krssak M, Shen J, Hundal RS, Trajanoski Z, Inzucchi S, Dresner A, Rothman DL \& Shulman GI. Impaired glucose transport as a cause of decreased insulin-stimulated muscle glycogen synthesis in type 2 diabetes. New England Journal of Medicine $1999 \quad \mathbf{3 4 1} 240-246$. (doi:10.1056/NEJM199907223410404)

149 Rothman DL, Shulman RG \& Shulman GI. 31P nuclear magnetic resonance measurements of muscle glucose-6-phosphate. Evidence for reduced insulin-dependent muscle glucose transport or phosphorylation activity in non-insulin-dependent diabetes mellitus. Journal of Clinical Investigation 199289 1069-1075. (doi:10.1172/JCI115686)

150 Shulman GI, Rothman DL, Jue T, Stein P, DeFronzo RA \& Shulman RG. Quantitation of muscle glycogen synthesis in normal subjects and subjects with non-insulin-dependent diabetes by $13 \mathrm{C}$ nuclear magnetic resonance spectroscopy. New England Journal of Medicine 1990322 223-228. (doi:10.1056/ NEJM199001253220403)

151 Fröjdö S, Vidal H \& Pirola L. Alterations of insulin signaling in type 2 diabetes: a review of the current evidence from humans. Biochimica et Biophysica Acta 20091792 83-92. (doi:10.1016/ j.bbadis.2008.10.019)

152 Morino K, Petersen KF \& Shulman GI. Molecular mechanisms of insulin resistance in humans and their potential links with mitochondrial dysfunction. Diabetes 200655 (Suppl 2) S9-S15. (doi:10.2337/db06-S002)

153 Bruce CR, Anderson MJ, Carey AL, Newman DG, Bonen A, Kriketos AD, Cooney GJ \& Hawley JA. Muscle oxidative capacity is a better predictor of insulin sensitivity than lipid status. Journal of Clinical Endocrinology and Metabolism $2003 \mathbf{8 8}$ 5444-5451. (doi:10.1210/jc.2003-030791)

154 Nyholm B, Nielsen MF, Kristensen K, Nielsen S, Ostergard T, Pedersen SB, Christiansen T, Richelsen B, Jensen MD \& Schmitz O. Evidence of increased visceral obesity and reduced physical fitness in healthy insulin-resistant first-degree relatives of type 2 diabetic patients. European Journal of Endocrinology 2004 150 207-214. (doi:10.1530/eje.0.1500207)

155 Wei M, Gibbons LW, Mitchell TL, Kampert JB, Lee CD \& Blair SN. The association between cardiorespiratory fitness and impaired fasting glucose and type 2 diabetes mellitus in men. Annals of Internal Medicine 1999130 89-96. (doi:10.7326/0003-4819130-2-199901190-00002)

156 Venables MC, Achten J \& Jeukendrup AE. Determinants of fat oxidation during exercise in healthy men and women: a crosssectional study. Journal of Applied Physiology 200598 160-167. (doi:10.1152/japplphysiol.00662.2003)

157 Davey GJG, Roberts JD, Patel S, Pierpoint T, Godsland IF, Davies B \& McKeigue PM. Effects of exercise on insulin resistance in South Asians and Europeans. Journal of Exercise Physiology Online 2000 3 12-22.

158 Cersosimo E \& DeFronzo RA. Insulin resistance and endothelial dysfunction: the road map to cardiovascular diseases. Diabetes/Metabolism Research and Reviews 200622 423-436. (doi:10.1002/dmrr.634)

159 Kim J, Montagnani M, Koh KK \& Quon MJ. Reciprocal relationships between insulin resistance and endothelial dysfunction. Circulation 2006113 1888-1904. (doi:10.1161/ CIRCULATIONAHA.105.563213)

160 Cubbon RM, Murgatroyd SR, Ferguson C, Bowen TS, Rakobowchuk M, Baliga V, Cannon D, Rajwani A, Abbas A, Kahn M et al. Human exercise-induced circulating progenitor cell mobilization is nitric oxide-dependent and is blunted in South Asian men. Arteriosclerosis, Thrombosis, and Vascular Biology 201030 878-884. (doi:10.1161/ATVBAHA.109.201012)

161 Murphy C, Kanaganayagam GS, Jiang B, Chowienczyk PJ, Zbinden R, Saha M, Rahman S, Shah AM, Marber MS \& Kearney MT. Vascular dysfunction and reduced circulating endothelial progenitor cells in young healthy UK South Asian men. Arteriosclerosis, Thrombosis, and Vascular Biology 200727 936-942. (doi:10.1161/01.ATV.0000258788.11372.d0)

162 Jin RC \& Loscalzo J. Vascular nitric oxide: formation and function. Journal of Blood Medicine 20102010 147-162. (doi:10.2147/ JBM.S7000) 
163 Nofer JR, van der Giet M, Tolle M, Wolinska I, von Wnuck LK, Baba HA, Tietge UJ, Godecke A, Ishii I, Kleuser B et al. HDL induces NO-dependent vasorelaxation via the lysophospholipid receptor S1P3. Journal of Clinical Investigation 2004113 569-581. (doi:10.1172/JCI200418004)

164 Chambers JC, McGregor A, Jean-Marie J \& Kooner JS. Abnormalities of vascular endothelial function may contribute to increased coronary heart disease risk in UK Indian Asians. Heart 199981 501-504. (doi:10.1136/hrt.81.5.501)

165 Din JN, Ashman OA, Aftab SM, Jubb AW, Newby DE \& Flapan AD. Increased arterial stiffness in healthy young South Asian men. Journal of Human Hypertension 200620 163-165. (doi:10.1038/ sj.jhh.1001961)

166 Hughes AD, Coady E, Raynor S, Mayet J, Wright AR, Shore AC, Kooner JS, Thom SA \& Chaturvedi N. Reduced endothelial progenitor cells in European and South Asian men with atherosclerosis. European Journal of Clinical Investigation 2007 37 35-41. (doi:10.1111/j.1365-2362.2007.01743.x)

167 Ajjan R, Carter AM, Somani R, Kain K \& Grant PJ. Ethnic differences in cardiovascular risk factors in healthy Caucasian and South Asian individuals with the metabolic syndrome. Journal of Thrombosis and Haemostasis $2007 \quad 5 \quad 754-760$. (doi:10.1111/j.1538-7836.2007.02434.x)

168 Bhalodkar NC, Blum S, Rana T, Bhalodkar A, Kitchappa R, Kim KS \& Enas E. Comparison of levels of large and small high-density lipoprotein cholesterol in Asian Indian men compared with Caucasian men in the Framingham Offspring Study. American Journal of Cardiology 200494 1561-1563. (doi:10.1016/j.amjcard.2004.08.040)

169 Cannon B \& Nedergaard J. Brown adipose tissue: function and physiological significance. Physiological Reviews $2004 \mathbf{8 4}$ 277-359. (doi:10.1152/physrev.00015.2003)

170 van Marken Lichtenbelt WD \& Schrauwen P. Implications of nonshivering thermogenesis for energy balance regulation in humans. American Journal of Physiology. Regulatory, Integrative and Comparative Physiology 2011301 R285-R296. (doi:10.1152/ ajpregu.00652.2010)

171 Bostrom P, Wu J, Jedrychowski MP, Korde A, Ye L, Lo JC, Rasbach KA, Bostrom EA, Choi JH, Long JZ et al. A PGC1$\alpha$-dependent myokine that drives brown-fat-like development of white fat and thermogenesis. Nature $2012 \mathbf{4 8 1} 463-468$. (doi:10.1038/nature10777)

172 Cani PD, Osto M, Geurts L \& Everard A. Involvement of gut microbiota in the development of low-grade inflammation and type 2 diabetes associated with obesity. Gut Microbes 20123 279-288. (doi:10.4161/gmic.19625)

Received 12 April 2013

Revised version received 16 July 2013

Accepted 12 August 2013 